\title{
BUILDING PRINCIPLES OF THE NETWORK RESOURCES AND THE NETWORK SERVICES PLATFORM ARCHITECTURES
}

\author{
Yuriy P. Kovalchuk, Oleg V. Kopiyka, Oksana O. Roiko \\ State University of Telecommunications, Kyiv, Ukraine
}

Background. Task of automation of productive and administrative processes, operating activity, general system providing, and also facilities, that provide creation, treatment, maintenance, moving away and transporting of information is actual. The united system of business processes allows conducting the synthesis of information and communication systems for national operator of telecommunications and informatization industry.

Objective. The objective is to develop the information systems architecture and the platforms of network resources and network services which are based on conception of the information and communication systems synthesis that automate the production and management processes, operation activities, production means and system-wide ensuring of the telecommunications operator.

Methods. The method of the communications infrastructure synthesis that receives convergent properties to provide personalized services to the end user, which is based on the developed methodology and methods and allows the client to implement the principle of self-configuration services to get the whole range of modern converged information and communication services to the agreed quality (QoS) is proposed.

Results. Architectures of telecommunication services capital of telecommunication operator are considered, which include the platforms of network resources and network services. The method of synthesis of communication infrastructure which gets convergence properties for the grant of personally services for end user is offered.

Conclusions. Description of methodological bases of synthesis of information-communication systems of telecommunication operator is presented, here, the synthesis of the systems is given by possibility to create the unique informative platform which is presented as universal architecture information and communication systems.

Keywords: information and communication systems, telecommunications operator; information systems architecture and platforms of network resources and network services.

\section{Introduction}

The main objective of these studies is to conduct a synthesis of the information and communication systems (ICS) of national telecommunications operator and informatization that automates production and management processes, operations, equipment manufacturing, system-wide security, and tools that enable the creation, processing, preservation, removal and transport information (Fig. 1) using a single system of business processes [1-4].

This ICS synthesis allows creating a single information platform that we represent as universal ICS architecture (UAICS) (Fig. 2).
For telecommunications operator UAICS is regarded as a single for:

- All types of networks (including network service), optical transport network, Internet network (data network), fixed telephone network, mobile phone network.

- All types of products, customers, services, resources, aspects of company management and business of company.

A very important requirement is that UAICS should not change when you change the product structure, market requirements or company structure.

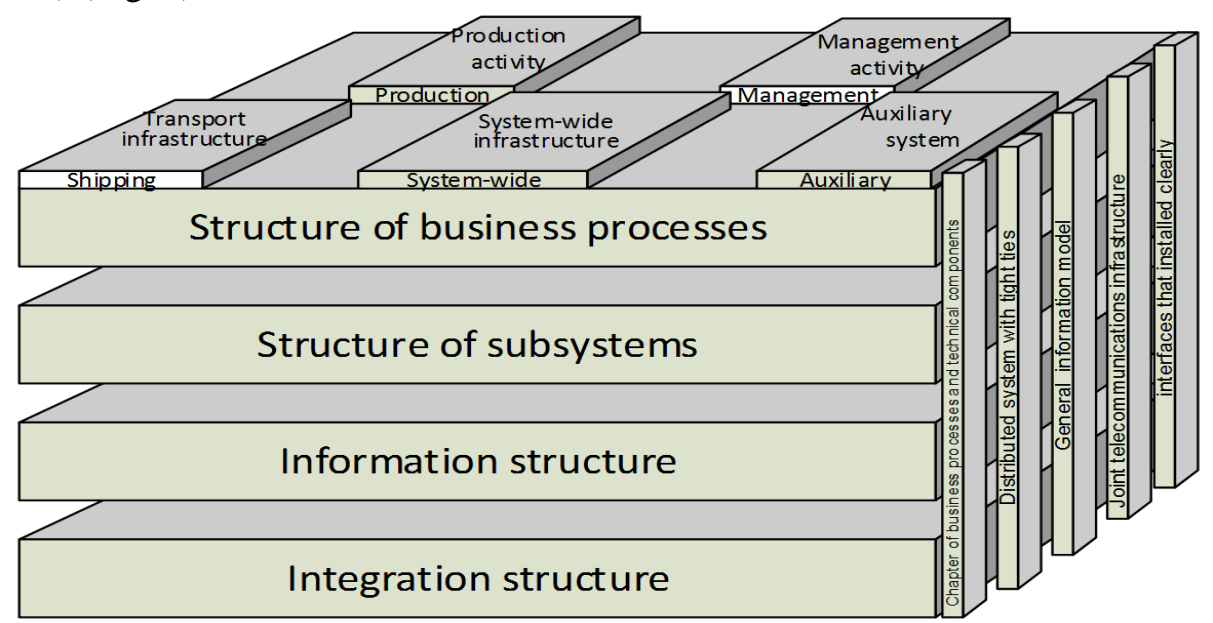

Fig. 1 Single information platform

ISSN 2312-4121, Information and Telecommunication Sciences, 2015, Volume 6, Number 2

(C) 2015, National Technical University of Ukraine "Kyiv Polytechnic Institute" 
Standardization UAICS provides:

- Determination of complete list of component architecture.
- Determination of the functional boundary components.

- Determination of interfaces (protocols) components interaction.
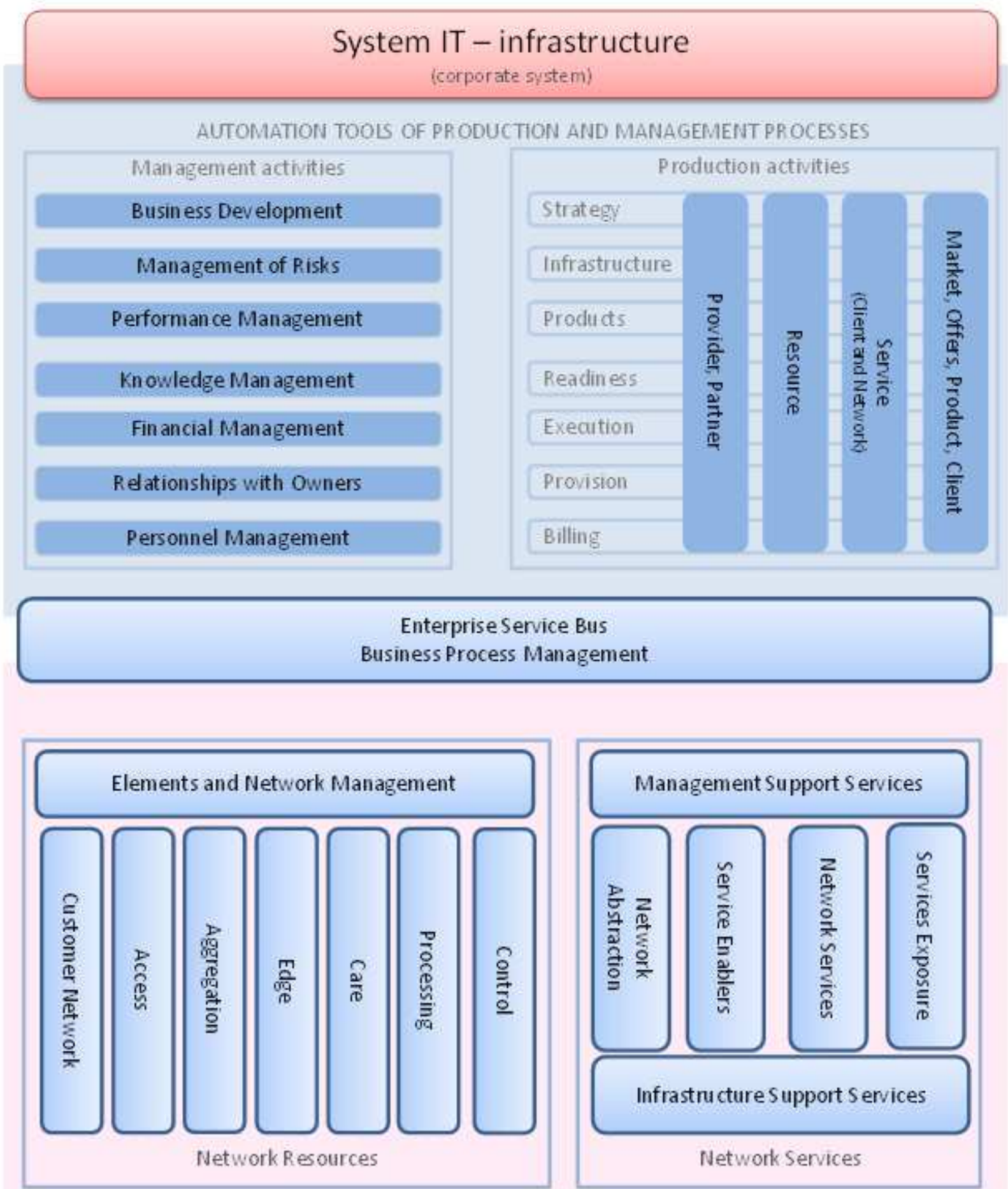

Manufacture of Communication services via

\section{Data Center (system IT - infrastructure)}

Fig. 2 Highest level of information systems architecture 
The main purpose of the architecture standardization is reduction of term for implementation services in company, by using reducing time for implementation and upgrading of information systems, and improves the efficiency of system implementation and reduces costs for their creation and operation through:

- Exclusion of functions duplication.

- Using the open interfaces.

- Using the repeated similar elements.

Conformance of the Architecture to the general accepted standards and concepts in the telecommunications and IT fields (Frameworx, TM Forum, eTOM, TAM, SID, SDF, ETSI TISPAN, etc.) are established during the research.

\section{Formulation of the problem}

The classification of information and communication systems of operator is conducted on the field of use. Information systems can belong to one of three classes:

- Automation Tools of production ( $\mathrm{Vv}$ ) and service management processes of operator $(\mathrm{Vu})$, which provide automated collection, storage, processing and issuance of necessary information for management functions. All processes related to the lifecycle of services, resources, provide the technology of customer service (customers) and maintenance services of sales services and accounting of revenue from them. Subject area of the systems in this class operates with the essence "service" as a commodity that has value added. The customer buys the service as a commercial product.

- Automation Tools of network services production (Vp). Information Systems of the technical processes Management that provide equipment control, technological modes in automatic production cycle of the network services, granting network services based on functional capability of equipment's construction unit. Subject area of the systems in this class operates with the essence "network service" which is not a commodity and doesn't offer on the market.

- Tools of system-wide software (Cs) (they are infrastructure in the relation to the first two).

Within a single class of system, covering certain functional areas, are grouped in the platform, which in turn consist of complexes.
There are platforms that are included to the class of automation tools of production and management processes: BSS).

$V u$ - automation of production activities (OSS /

$V v$ - automation of management activities (ESS).

There are platforms that are included to the class of public communication production services $(V p)$ :

$V p_{1}$ - network resources.

$V p_{2}$ - network services.

Complexes that include to tools of system-wide software $(C s)$ :

$C s_{1}$ - system of IT- infrastructure, alone:

$C s_{11}$ - corporate systems.

$C s_{12}$ - systems of general use.

$C s_{2}$ - Enterprise Service Bus - Business Process Management (the Platform of Information Exchange (PIE) and business process management (BPM)).

In this article we consider in detail the architectures structure of the network resources and the network services platform

\section{Architecture of the network resources platform}

We distinguish four networks (transport, IP-network, mobile network and fixed communication). We are defining eight complexes of the network resources (levels) to unify architectures for each network:

$V p_{1 \mathrm{i}}=\mathrm{f}\left(\mathrm{m}_{1}, \mathrm{~m}_{2}, \mathrm{~m}_{3}, \mathrm{~m}_{4}, \mathrm{~m}_{5}, \mathrm{~m}_{6}, \mathrm{~m}_{7}, \mathrm{~m}_{8}\right)$, where $\mathrm{m}_{1} \quad$ customer's network; $\mathrm{m}_{2}$ - access; $\mathrm{m}_{3}$ - aggregation; $\mathrm{m}_{4}$ - edge; $\mathrm{m}_{5}$ - core; $\mathrm{m}_{6}-$ data processing; $\mathrm{m}_{7}$ - signaling processing; $\mathrm{m}_{8}-$ management of the network resources.

Ability of creating network services is defined by the modern network resources platform possibilities.

The network resources platform interacts with the network services platform solely through the level of signaling processing.

All systems of the network resources platform are operated exclusively by the essence "Resource|".

Functional destination of eight network resources platform's complexes (levels) can be represented as follows (Fig. 3). 


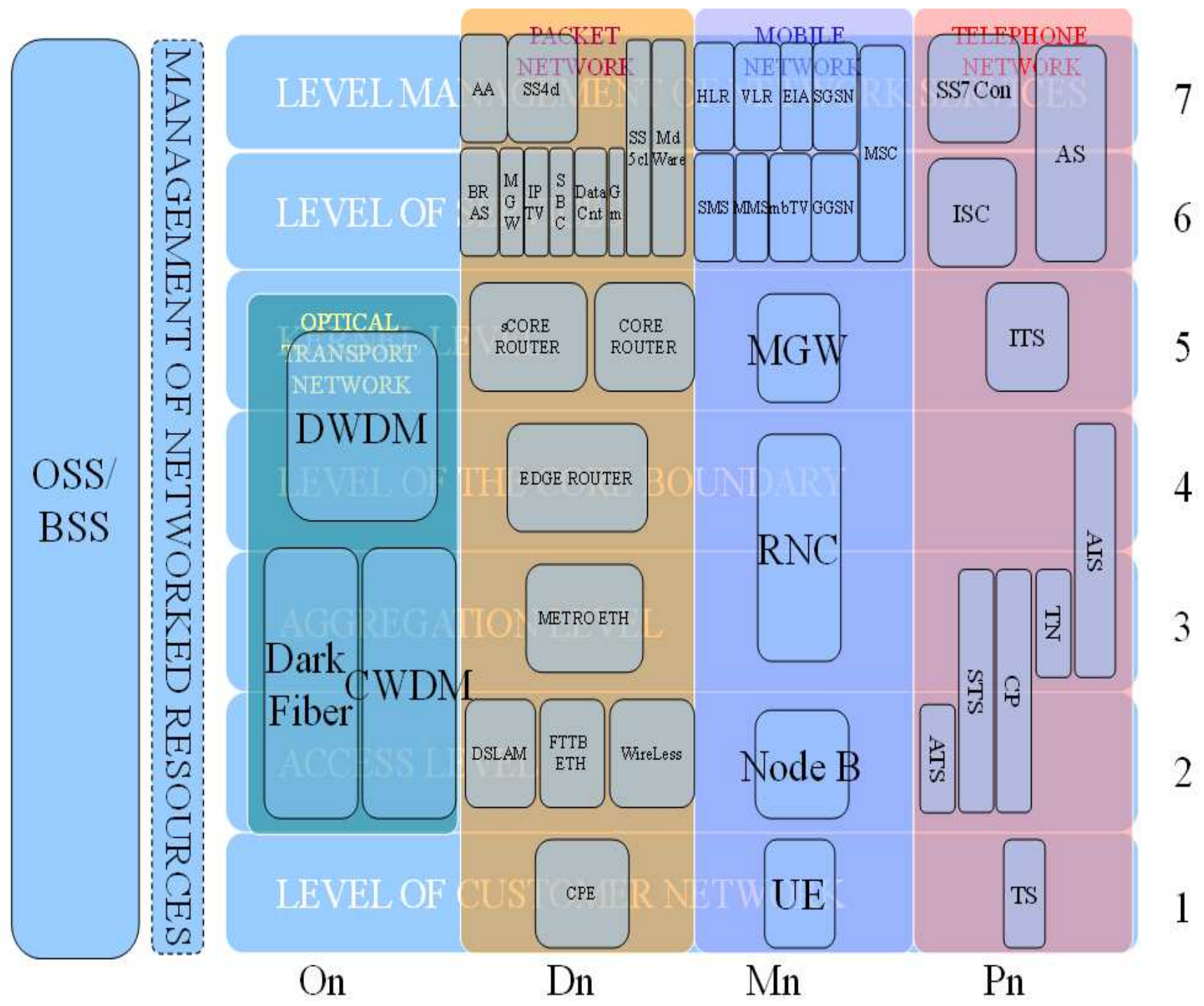

Fig. 3 Architecture of the network resources platform

The client's network level performs the following tasks:

$\mathrm{m}_{11}$ - Input - output of the information.

$\mathrm{m}_{12}$ - data processing.

$\mathrm{m}_{13}-$ connecting client terminals.

$\mathrm{m}_{14}$ - transporting of the traffic from client terminals with access level .

The access Level performs the following tasks:

$\mathrm{m}_{21}$ - connecting client networks (in degenerate case - the client terminal).

$\mathrm{m}_{22}$ - transporting of the traffic from client's network to the level of aggregation.

The aggregation level performs the following tasks:

$\mathrm{m}_{31}$ - connecting of access nodes (optical, xDSL, wireless).

$\mathrm{m}_{32}$ - transporting of the traffic from access nodes to the level of the edge.

The edge level performs the following tasks:

$\mathrm{m}_{41}$ - connecting aggregation nodes.

$\mathrm{m}_{42}-$ skipping (using policies) data and signaling in the network (RCEF, C-BGF). $\mathrm{m}_{43}$ - recoding data on transitions to other networks (T-MGF).

$\mathrm{m}_{44}$ - transporting of the traffic from aggregation nodes to the core level or to other networks.

The core Level performs the following tasks:

$\mathrm{m}_{51}$ - connecting edge routers (user access, data processing, signaling processing, connections with operators).

$\mathrm{m}_{52}$ - transporting of the traffic between edge routers.

The data processing level performs following tasks:

$\mathrm{m}_{61}$ - processing of client data (MRFP).

The signaling processing level performs the following tasks:

$\mathrm{m}_{71}$ - management of the client requests for data exchange (AGCF, P-CSCF, A-RACF, SPDF).

$\mathrm{m}_{72}$ - management of requests for processing client's data (MRFC).

$\mathrm{m}_{73}$ - management of requests for exchange of data with other networks (BGCF, MGCF, SGF). 
$\mathrm{m}_{74}$ - processing software including routing all requests (I / S-CSCF).

Management of the network resources Level performs tasks of interaction with the OSS systems.

The network resources platform's opportunities define the ability of network services creation [5-9].

The network resources platform doesn't include application servers, account management and others. The network services platform provides this functionality. The network resources platform interacts with the network services platform solely through the level of signaling processing. The network resources platform interacts with the automation of production activity platform through the management of the network resources level and signaling processing level.

\section{Architecture of the network services platform}

The network services platform is a very important element of the architecture, especially in the case of provision of telecommunication services. Main objective of this platform is reduction of term for implementation services in company, by using reducing time for implementation and upgrading of products and improve the efficiency of product introduction and reduce costs for their creation and operation due to: avoided functions duplication, using the open interface, using the repeated similar elements.

The network services platform $V p_{2 i}$ consists of six complexes (levels) (Fig. 4): $V p_{2 \mathrm{i}}=$ $\mathrm{f}\left(\mathrm{p}_{1}, \mathrm{p}_{2}, \mathrm{p}_{3}, \mathrm{p}_{4}, \mathrm{p}_{5}, \mathrm{p}_{6}, \mathrm{p}_{7}, \mathrm{p}_{8}\right)$, where

$\mathrm{p}_{1}-$ abstraction of the network resources.

$\mathrm{p}_{2}$ - internal interfaces of the network services.

$\mathrm{p}_{3}-$ logic of the network services.

$\mathrm{p}_{4}$ - external interfaces of the network services.

$\mathrm{p}_{5}-$ general functions of the network services.

$\mathrm{p}_{6}-$ management of the network services.
The level of the network resources abstraction includes network adapters (low level network activators to ensure the access to appropriate elements of the network and network capabilities). The level of abstraction of network resources is a network abstraction layer. It operates with the essence "process operation".

Level of internal interfaces of the network services abstracts for a level which is located above - network service capabilities. It operates with the essence "component of network services." A set of OSA / Parlay API is an example of this interface.

Level of the network services logic is abstracts for a level which is located above - facilities of the implementation services in application servers. In fact, a finishing network service appears at this level, which has a customer value or can be incorporated into other services. Network service can be a part of the company's products or can be set as an external product (outsourcing) and incorporated into the products of third companies. It operates with the essence of "network service".

The level of external interfaces of the network services provides the access to third parties services. The set Parlay-X API is an example of this interface.

The level of the general functions network services includes components necessary for the realization of services, their components and interfaces.

This level describes the prerequisites for the proper functioning of the service. The level of the general functions network services includes functionality of the SDF Infrastructure Support Service (TM Forum). Level provides functionality:

$\mathrm{p}_{51}$ - management of the sessions.

$\mathrm{p}_{52}$ - identity management.

$\mathrm{p}_{53}-$ account management.

$\mathrm{p}_{54}-$ resource management.

$\mathrm{p}_{55}-$ service catalog.

$\mathrm{p}_{56}$ - environment runtime. 


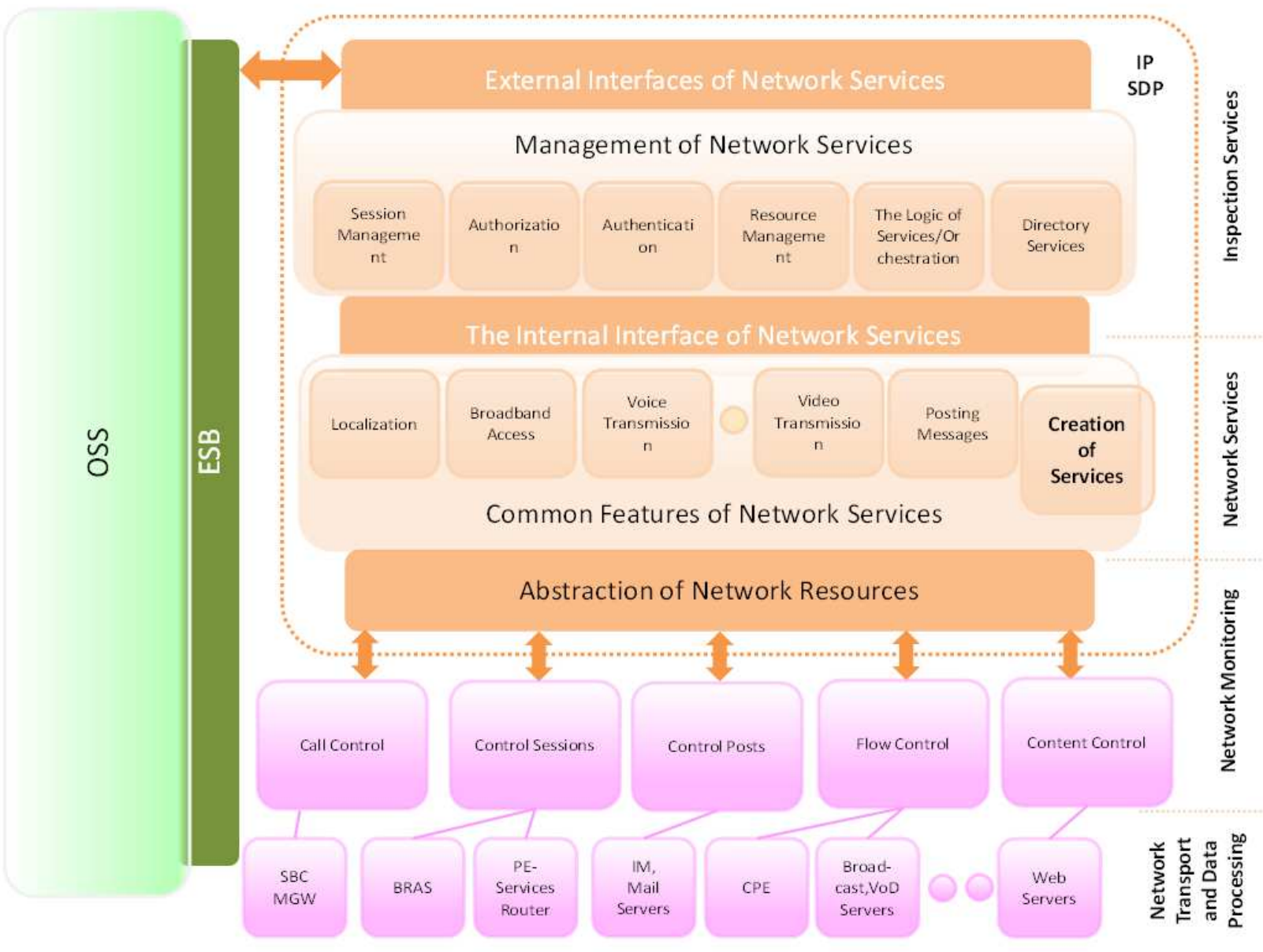

Fig. 4 Architecture of the network services platform

The level of network services management provides the life cycle support of the network service. The level of network services management includes functionality of the SDF Management Support Service (TM Forum).

The network service platform interacts with the network resources platform only through the level of the network resources abstraction.

The service platform interacts with the operational processes support platform through the level of the network services management and logic of network services, within the providing of communication services. For these interfaces service platform gives data about consumption of services, and also takes commands for activation / deactivation of services on the network (while operational processes support platform has following functions: process the orders for the product, its decomposition of the services, running sequence of operations activation services on the network).

Platform of networking services in general operates with the essence of "network service".

Opportunities of the network services platform determine which services can be sold to consumers. This approach provides the opportunity for the formation of new telecommunication systems architecture and services by using "cloud technology".

\section{The method of communication infrastructure synthesis}

Let us consider the alternative optimum method of using the means of production in the provision of converged services. 


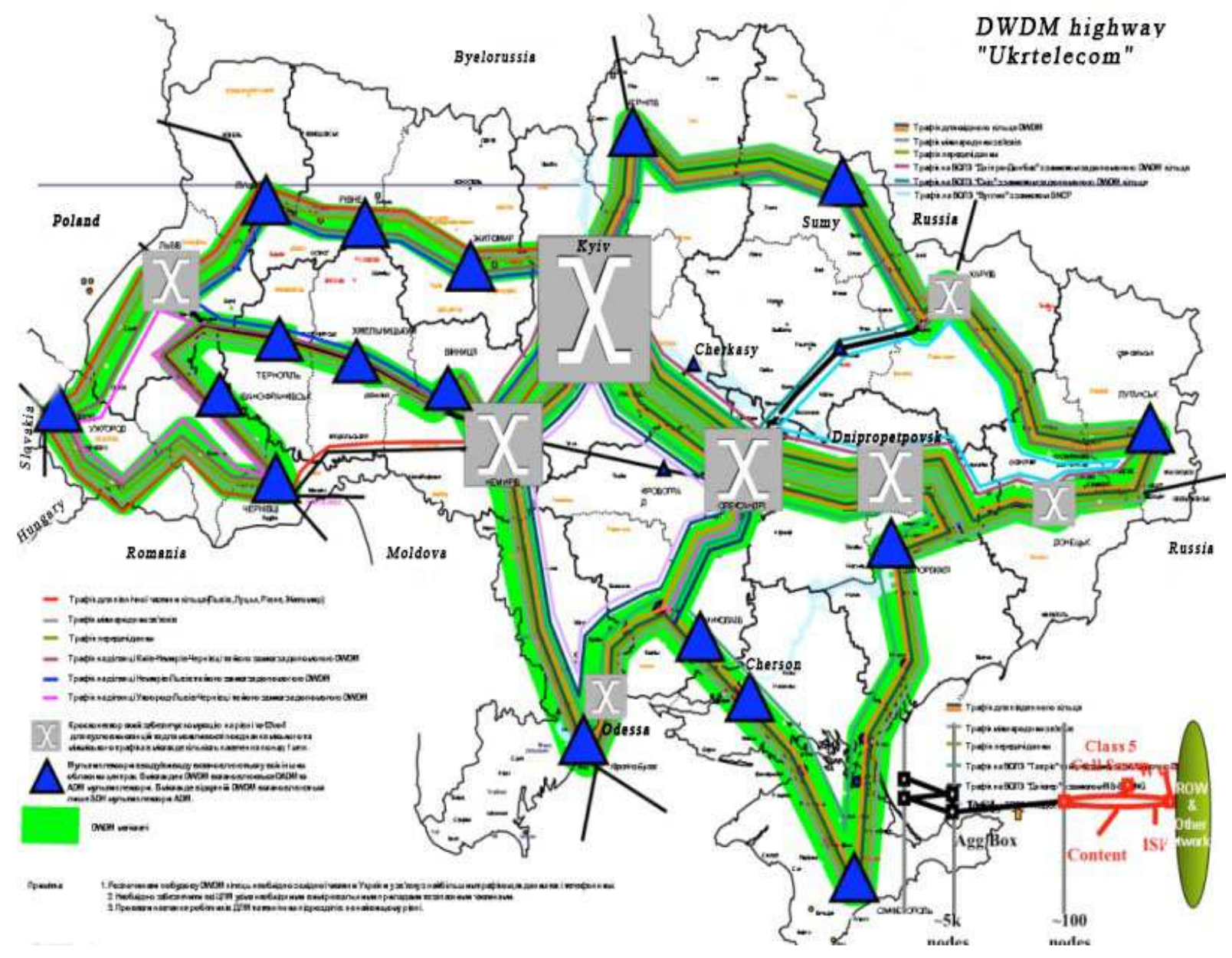

Fig. 5 DWDM highway "Ukrtelecom"

The following conclusion can be made according to the concept of communications infrastructure synthesis.

We've received multi service transport network (Fig. 5), thanks to technology development, which provided opportunities for convergence of transmitted Information.

Let us consider three main networks: mobile, data transmitting and the traditional phone network (Fig. 6) to test the method of communication infrastructure synthesis that receives convergence properties to provide personalized services to the end user. The essential task is the use of convergence networks to provide personalized services to the end user, and in such case realized the principle of self configuration of services and the opportunity to receive the full range of today's converged ICT services with consistent quality (QoS).
Due to the fact that convergence takes place at level of transporting data (Fig. 7) we consider five levels in the method: services (data processing) core, core boundary (edge), aggregation and access.

Fig. 8 shows a graph of the organization convergence of three networks with ordinal function $O\left(x_{i j}\right)=F\left(E_{0}, E_{1}, E_{2}, E_{3}, E_{4}\right)$, where $E k$ - levels: services, core, core boundary, aggregation and access. Each level contains three peaks $\left(x_{k 1}, x_{k 2}, x_{k 3}\right)$. Each arc of the graph necessarily connects tops of two adjacent levels. Each of the (Ek) level fit the corresponding element of the network (Fig. d). The tops are the network equipment $\left(y_{i j}\right.$ - potential top) and arcs are transition while transporting data from one level to another, and the end of the arc indicates the equipment by which data is being transferred, and the potential arc $c_{i j}$ - summarized the costs of information transmission. 


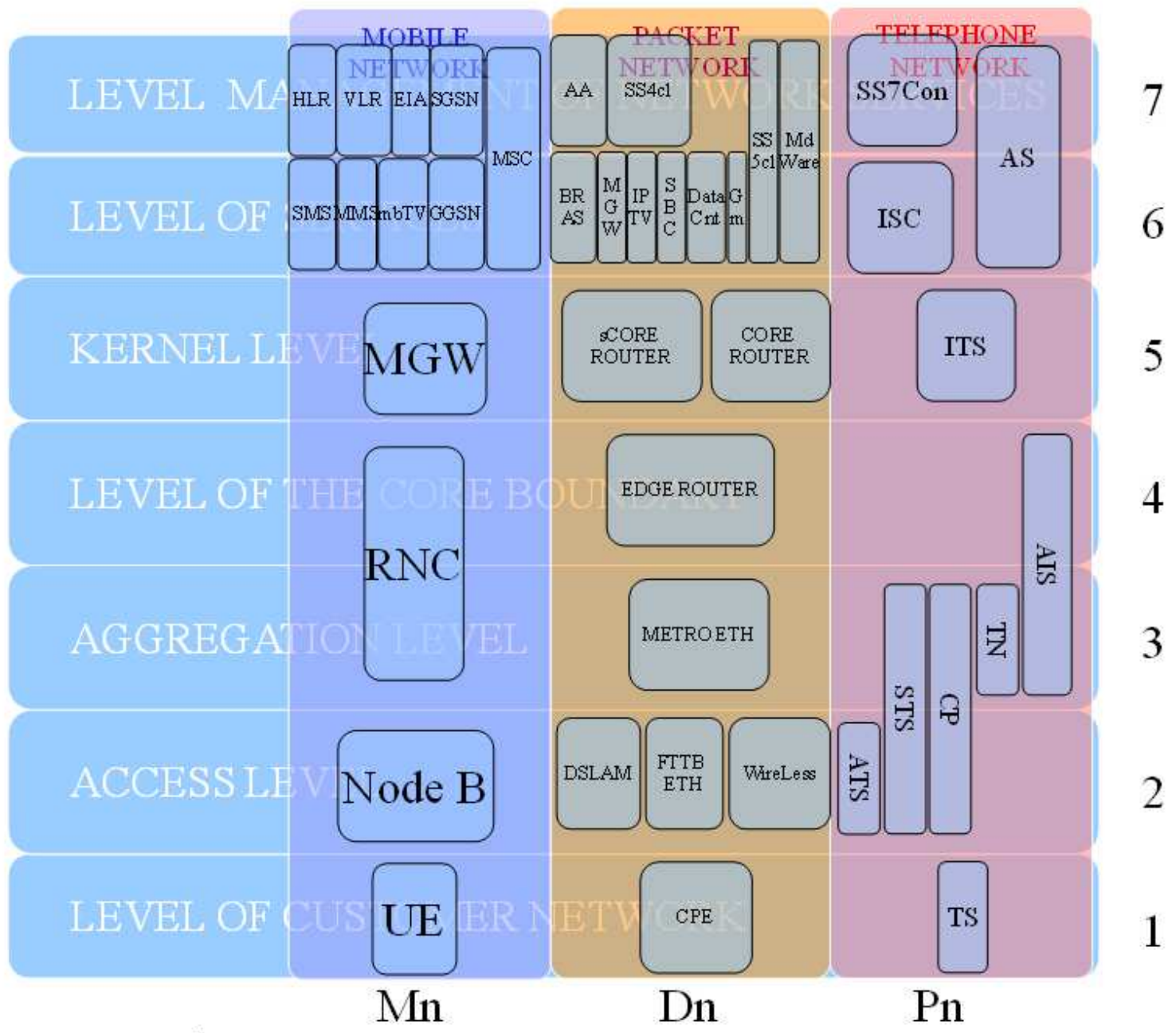

Fig. 6

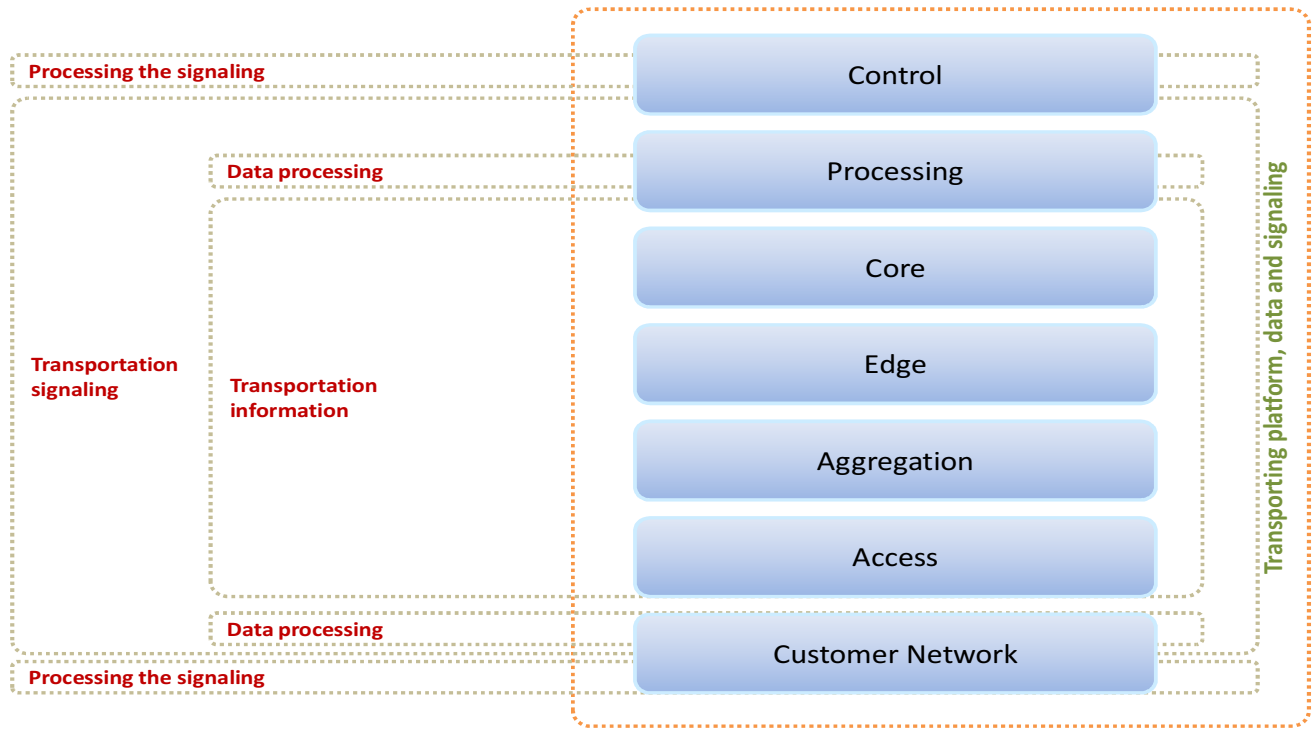

Fig. 7 


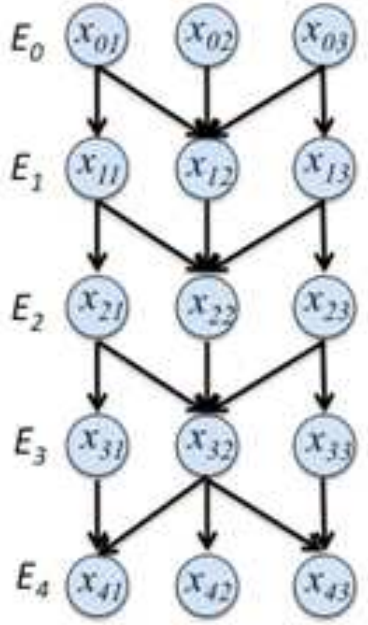

Fig. 8 a

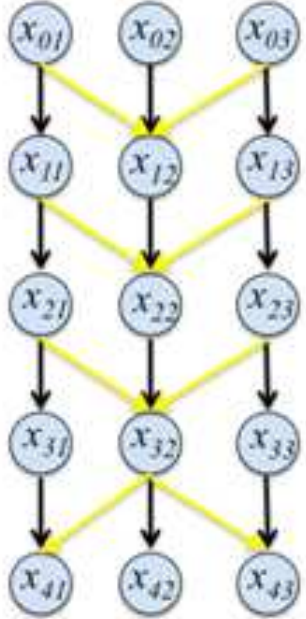

Fig. 8 b

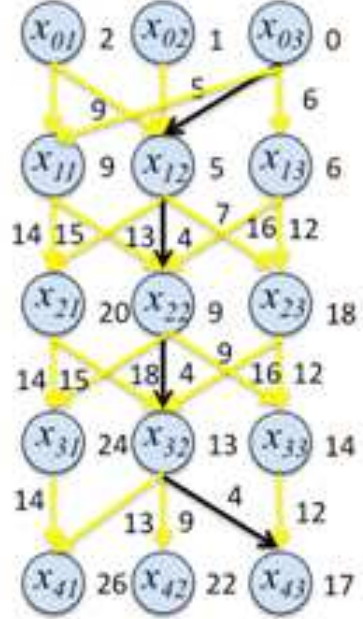

Fig. $8 \mathrm{c}$
Graph of the fig. $8 \mathrm{~b}$ is the case when there is no convergence of networks.

Consider the case of upgrading networks, such as data network use for voice transmission (Fig. $8 \mathrm{c}$ ). Consider the algorithm of optimal choice selection:

1. Assume that $c_{01}=2 ; c_{02}=1 ; c_{03}=0, y_{0}=\min \left(c_{0 j}\right)$. This means that usage for this case equipment of the telephone network to provide services is economically reasonable.

2. Define the potential of the first level tops according to the formula: $y_{1}=\min \left(y_{03}+c\left(x_{03}, x_{l j}\right)\right)$.

Thus: $y_{11}=0+9=9 ; y_{12}=0+5=5 ; y_{13}=0+6=6 . y_{1}=y_{12}$.

3. Define the potential of the second level tops, according to the formula: $y_{i}=\min \left(y_{i-1 j}+c\left(x_{i-1 j}, x_{i j}\right)\right)$ :

$y_{2}=\min \left(y_{1 j}+c\left(x_{1 j}, x_{2 j}\right)\right)$

$y_{21}=\min (5+15,9+14)=20$

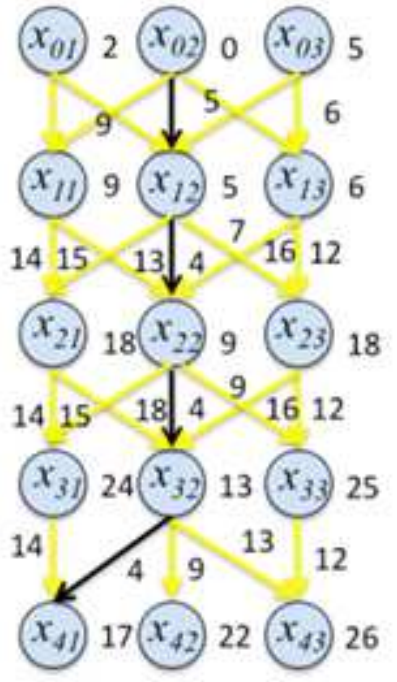

Fig. $8 \mathrm{~d}$ $y_{22}=\min (9+13,5+4,6+7)=9$

$y_{23}=\min (5+16,6+12)=18$

$y_{2}=y_{22}$.

4. Define the potential of the third level tops, according to the formula:

$y_{3}=\min \left(y_{2 j}+c\left(x_{2 j}, x_{i j}\right)\right)$

$y_{31}=\min (18+14,9+15)=24$

$y_{32}=\min (18+18,9+4,12+9)=13$

$y_{33}=\min (9+16,12+12)=24$

$y_{3}=y_{32}$.

5. Similarly, we define the potential tops of the fourth level, according to the formula $y_{4}=\min \left(y_{3 j}+c\left(x_{3 j}, x_{4 j}\right)\right)$ : $y_{4}=y_{43}$.

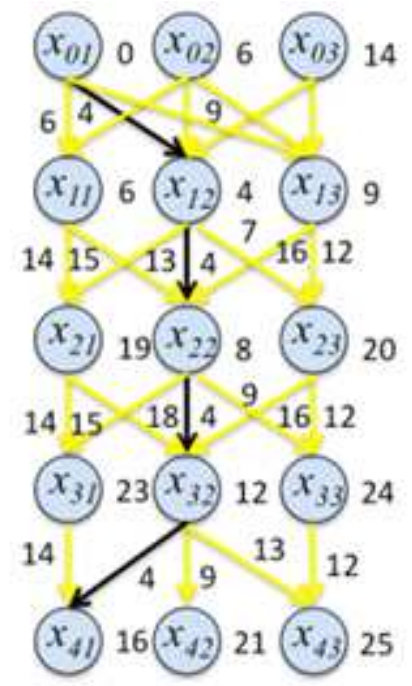

Fig. 8 e 
Consider the case of providing IPTV service (Stream TV through data network) to a mobile device (Fig. $8 \mathrm{~d}$ ). Consider the algorithm of optimal choice selection:

1. Assume that $c_{01}=2 ; c_{02}=0 ; c_{03}=5, y_{0}=\min \left(c_{0 j}\right)$. This means that usage for this case equipment of the data network to provide services is economically reasonable.

2. Define the potential of the first level tops, according to the formula: $y_{l}=\min \left(y_{l j}\right)$, where $y_{l j=}$ $y_{03}+c\left(x_{03}, x_{l j}\right)$. Thus: $y_{l}=y_{12}$.

3. Define the potential of the second level tops, according to the formula:

$y_{2}=\min \left(y_{1 j}+c\left(x_{1 j}, x_{2 j}\right)\right)$ :

$y_{2}=y_{22}$.

4. Define the potential of the third level tops, according to the formula:

$y_{3}=\min \left(y_{2 j}+c\left(x_{1 j}, x_{2 j}\right)\right)$ :

$y_{i j}=y_{32}$.

5. Similarly, we define the potential of the fourth level tops, according to the formula $y_{4}=\min \left(y_{3 j}+c\left(x_{3 j}, x_{4}\right.\right.$ j)): $y_{4}=y_{41}$.

Consider the case of $4 \mathrm{G}$ mobile communications standard LTE (Fig. 8 e). Consider the algorithm of optimal choice selection:

1. Assume that $c_{01}=0 ; c_{02}=6 ; c_{03}=14, y_{0}=\min \left(c_{0 j}\right)$. This means that usage for this case equipment of the data network to provide services is economically reasonable.

2. Define the potential of the first level tops: the formula $y_{l}=\min \left(y_{l j}\right)$, where $y_{l j}=y_{03}+c\left(x_{03}, x_{l j}\right)$. Thus: $y_{l}=$ $y_{12}$.

3. Define the potential of the second level tops according to the formula

$y_{2}=\min \left(y_{1 j}+c\left(x_{1 j}, x_{2 j}\right)\right)$ :

$y_{2}=y_{22}$.

4. Define potential of the third level tops according to the formula

$y_{3}=\min \left(y_{2 j}+c\left(x_{2 j}, x_{3 j}\right)\right)$ :

$y_{3}=y_{32}$.

5. Similarly, we define potential of the fourth level tops according to the formula $y_{4}=\min \left(y_{3}{ }_{j}+c\left(x_{3 j}, x_{4}\right)\right)$ : $y_{4}=y_{41}$.

\section{Conclusions}

The article describes the methodological foundations of information and communication technology systems synthesis of telecom operator, while systems synthesis can create a unified information platform, which is presented as a universal architecture of information and communication systems.

Architectures of the network resources platform and the network services platform are presented.

Method of communication infrastructure synthesis that gets the convergence properties to provide personalized services to the end user is proposed.

\section{References}

1.V. Redko, I. Sergienko, A. Stukalo application systems. Architecture, construction, development. - K.: Nauk. dumka, 1992. - 320 p.

2. V. Repin, V. Elyferov Process approach to management: Business Process Modeling. - M .: RIA "Standards and quality" 2004. - 408 p.

3. Rinks, D., A heuristic approach to aggregate production scheduling using linguistic variables:

Methodology and Application" in Yager R.R.(ed.)

"Fuzzy Set and Possibility Theory", Recent advances. / - M .: Radio and Communications, 1986. - 408c.- 408s.

4. O. Kopeika, I. Tarasenko, A. Kisselevskiy, A. Karichenskiy, T. Valiulin. Softline applies TMF standards as a guide when building Resource Inventory solution for nation-wide carrier Ukraine Telecom // TM Forum Case Study Handbook, Volume 3, May 2007. P. 27.

5. A. Shmalko The digital telecommunications network: Fundamentals of Scheduling and building a. M .: Eko-Trendz, 2001. - 282 p.

6. CCITT Recommendation X.700 (09/92): Data Communication Networks: Management framework for Open Systems Interconnection (OSI) for CCITT applications / International Telecommunications Union. - Geneva, 1992.

7. Choi M.-J., Hong J.W.-K. Towards Management of Next Generation Networks // IEICE Transaction Communications E Series B. - 2007. - Vol. 90. - No. 11. - P. 3004-3014.

8. Rubinstein, M, Duarte OC, Pujolle G. Evaluating the Network Performance Management Based on Mobile Agents // Proc. of 2nd International Workshop of Mobile Agents for Telecommunication Applications (MATA), Paris, France, September 2000.

9. O. Kopiyka, The architecture of network in the modern data-centers /O. Kopiyka// Scientific notes Ukrainian Research Institute of Communications. 2014. - № 2 (30). - P.34 - 41.

Received in final form on November 05, 2015 


\section{Ковальчук Ю.П., Копійка О.В., Ройко О.О.}

Принципи побудови архітектур мережевих ресурсів та мережних послуг.

Проблематика. Завдання автоматизації виробничих та управлінських процесів, операційної діяльності, загальносистемного забезпечення, а також засобів, які забезпечують створення, обробку, збереження, видалення та транспортування інформації є актуальним. Єдина система бізнес-процесів дозволяє провести синтез інформаційнокомунікаційні системи національного оператора галузі телекомунікацій та інформатизації.

Мета досліджень. Метою є розробка архітектури інформаційних систем та платформ мережевих ресурсів та мережних послуг на базі концепції синтезу інформаційно-комунікаційних систем, які автоматизують виробничий та управлінський процеси, операційну діяльність, засоби виробництва та загальносистемне забезпечення телекомунікаційного оператора.

Методика реалізації. Запропоновано метод синтезу комунікаційної інфраструктури, яка отримує конвергентні властивості для надання персоналізованих послуг кінцевому користувачу, який базується на розроблених методології і методах та дозволяє клієнту реалізувати принцип самоконфігурації послуг та отримувати увесь спектр сучасних конвергентних інформаційно-комунікаційних послуг з узгодженою якістю (QoS).

Результати досліджень. Розглянуто архітектури засобів виробництва послуг зв'язку загального користування телекомунікаційного оператора, які включають платформи мережевих ресурсів та мережевих послуг. Запропоновано метод синтезу комунікаційної інфраструктури, яка отримує конвергентні властивості для надання персоналізованих послуг кінцевому користувачу.

Висновки. Надано опис методологічних основ синтезу інформаційно-комунікаційних систем телекомунікаційного оператора, при цьому, синтез систем дає змогу створити єдину інформаційну платформу, яка представлена у вигляді універсальної архітектури інформаційно-комунікаційних систем.

Ключові слова: інформаційно-комунікаційні системи; телекомунікаційний оператор; архітектури інформаційних систем та платформ мережевих ресурсів та мережних послуг

\section{Ковальчук Ю.П., Копейка О.В., Ройко О.О.}

Принципы построения архитектур сетевых ресурсов и сетевых услуг.

Проблематика. Задание автоматизации производственных и управленческих процессов, операционной деятельности, общесистемного обеспечения, а также средств, которые обеспечивают создание, обработку, сохранение, удаление и транспортировку информации является актуальным. Единая система бизнес-процессов позволяет провести синтез информационно-коммуникационные системы национального оператора отрасли телекоммуникаций и информатизации.

Цель исследований. Целью является разработка архитектуры информационных систем и платформ сетевых ресурсов и сетевых услуг на базе концепции синтеза информационно- коммуникационных систем, которые автоматизируют производственный и управленческий процессы, операционную деятельность, средства производства и общесистемное обеспечение телекоммуникационного оператора.

Методика реализации. Предложен метод синтеза коммуникационной инфраструктуры, которая получает конвергентные свойства для предоставления персонализованных услуг конечному пользователю, который базируется на разработанных методологии и методах и позволяет клиенту реализовать принцип самоконфигурации услуг и получать весь спектр современных конвергентных информационно-коммуникационных услуг с согласованным качеством (QoS).

Результаты исследований. Рассмотрены архитектуры средств производства услуг связи общего пользования телекоммуникационного оператора, которые включают платформы сетевых ресурсов и сетевых услуг. Предложен метод синтеза коммуникационной инфраструктуры, которая получает конвергентные свойства для предоставления персонализованных услуг конечному пользователю.

Выводы. Представлено описание методологических основ синтеза информационно- коммуникационных систем телекоммуникационного оператора, при этом, синтез систем дает возможность создать единственную информационную платформу, которая представлена в виде универсальной архитектуры информационно коммуникационных систем.

Ключевые слова: информационно-коммуникационные системы; телекоммуникационный оператор; архитектуры информационных систем и платформ сетевых ресурсов и сетевых услуг. 